\title{
Synthesis, Characterization, and Biological Studies of New Ruthenium Polypyridyl Complexes Containing Noninnocent Ligands
}

\author{
Sofia Taheri, ${ }^{1}$ Mahdi Behzad, ${ }^{1}$ Hossein Nazari, ${ }^{2}$ and Ali Khaleghian ${ }^{2}$ \\ ${ }^{1}$ Department of Chemistry, Faculty of Science, University of Semnan, P.O. Box 35195-363 Semnan, Iran \\ ${ }^{2}$ Biochemistry Department, Faculty of Medicine, Semnan University of Medical Science, Semnan, Iran \\ Correspondence should be addressed to Mahdi Behzad; mbehzad@semnan.ac.ir
}

Received 13 November 2012; Accepted 29 November 2012

Academic Editors: B. Sohrabi and B. Yan

Copyright (C) 2013 Sofia Taheri et al. This is an open access article distributed under the Creative Commons Attribution License, which permits unrestricted use, distribution, and reproduction in any medium, provided the original work is properly cited.

Two new polypyridyl complexes $\left[\mathrm{Ru}(\mathrm{ttp})\left(\mathrm{L}^{1}\right) \mathrm{Cl}\right] \mathrm{PF}_{6}(\mathbf{1})$ and $\left[\mathrm{Ru}(\mathrm{ttp})\left(\mathrm{L}^{2}\right) \mathrm{Cl}\right] \mathrm{PF}_{6}(\mathbf{2})$ with noninnocent o-benzoquinonediimine $\left(\mathrm{L}^{1} ;\right.$ bqdi) and 4,5-dimethyle-o-benzoquinonediimine $\left(\mathrm{L}^{2} ; 4,5\right.$-di-Mebqdi) ligands were synthesized and characterized (ttp $=4^{\prime}$-p-toloyle-2,2': $6^{\prime}, 2^{\prime \prime}$-terpyridine). Cyclic voltammetry studies suggest that noninnocent ligands are coordinated in their benzoquinonediimine form. Preliminary ruthenium complexes-induced DNA dysfunction was studied on E. coli GM109 DNA by means of melting temperature analysis (Tm). Our results suggest that complex (2) inhibited DNA function more strongly compared to (1). Antibacterial activities of the complexes against $E$. coli bacteria were studied, and Minimum inhibitory concentration (MIC) values were evaluated. Both complexes showed great antibacterial activities.

\section{Introduction}

Identifying the molecules that are capable of binding and cleaving DNA has attracted considerable interest over the last few decades [1]. In this regard, ruthenium-containing complexes have obtained great considerations [2-13]. Although the investigation of the interactions of other transition metal complexes with DNA and RNA has been the subject of several researches [14-17], more attention has been given to ruthenium complexes [18-22]. These investigations are very important in the development of new therapeutic reagents and DNA molecular probes [23,24]. Ruthenium complexes are also well suited for medical applications due to their favorable rate of ligand exchange and their ability to mimic iron binding to certain biomolecules $[25,26]$. Therefore, the studies on the interaction of ruthenium compounds with DNA have led to the development of several rutheniumbased anticancer drugs $[27,28]$. As a result, a variety of $\mathrm{Ru}$ complexes, especially terpyridine complexes, have obtained considerable attention [29-31]. This is due to the benefit of high stability of their coordination compounds and the rich photochemical and electrochemical properties of their metal complexes which are found to promote DNA binding and cleaving. Furthermore, introduction of substituents in the 4 ' position of terpyridine can be easily achieved by available procedures, which gives the opportunity of fine tuning of the coordination environment. Many useful applications of these complexes require that the complexes bind to DNA through an intercalative mode as well as outer of double strand or both of side. Therefore, the vast majority of such studies have been focused on the modification of the intercalative and outercalative ligands [32-34]. Since the octahedral polypyridyl $\mathrm{Ru}(\mathrm{II})$ complexes bind to DNA in three dimensions, the ancillary ligands can also play an important role in governing DNA binding of these complexes. At the same time, varying substitutive group or substituent position in the ancillary ligand can also create some interesting differences in the space configuration and the electron density distribution of $\mathrm{Ru}(\mathrm{II})$ polypyridyl complexes, which will result in some spectral properties and different DNA-binding behaviors of the complexes and will be helpful to more clearly understand the binding 
mechanism of $\mathrm{Ru}(\mathrm{II})$ polypyridyl complexes to DNA [35, 36]. Considering the afore mentioned, herein we report the synthesis and characterization of two new polypyridyl complexes: $\left[\mathrm{Ru}(\mathrm{ttp})\left(\mathrm{L}^{1}\right) \mathrm{Cl}\right] \mathrm{PF}_{6}(\mathbf{1})$ and $\left[\mathrm{Ru}(\mathrm{ttp})\left(\mathrm{L}^{2}\right) \mathrm{Cl}\right] \mathrm{PF}_{6}(2)$ with noninnocent o-benzoquinonediimine $\left(\mathrm{L}^{1}\right.$; bqdi) and 4,5-dimethyle-o-benzoquinonediimine ( $\mathrm{L}^{2} ; 4,5$-di-Mebqdi) ligands. The interaction of these complexes with E. coli GM109 DNA was also studied by means of UV-Vis spectroscopy. Our results show that complex (2) with two methyl groups on the bqdi-type ligand interacts with $E$. coli GM109 DNA more strongly. Antibacterial activity of the two complexes was evaluated, and minimum inhibitory concentrations were obtained by the dilution method as recommended by NCCLS (National Committee for Clinical Laboratory Standards).

\section{Experimental}

All chemicals were of the highest purity and were used as received. All the synthesis and purifications were conducted in aerobic condition. Ttp (4'-p-toloyle- $2,2^{\prime}$ : $6^{\prime}, 2^{\prime \prime}$-terpyridine) was synthesized as described elsewhere [37]. E. coli GM109 DNA was extracted as described elsewhere [38, 39]. Tris(hydroxymethyl)aminomethane-HCl (trisbuffer) was prepared with deionized and degassed triple distilled water, and all of the DNA interaction studies were performed in this buffer $(\mathrm{pH}=7.2)$. Melting points were obtained on a thermoscientific 9100 apparatus. ${ }^{1}$ HNMR spectra were recorded on a $500 \mathrm{MHz}$ Bruker FT-NMR spectrometer using $\mathrm{CDCl}_{3}$ and $\mathrm{DMSO}-\mathrm{d}_{6}$ solvents; chemical shifts $(\delta)$ are given in ppm. IR spectra were obtained as $\mathrm{KBr}$ plates using a Bruker FT-IR instrument, and UVVis spectra were obtained as acetonitrile solutions on a Shimadzu UV-1650PC spectrophotometer or UV-Visible Milton Roy 1201 spectrophotometer apparatus. Elemental analysis $(\mathrm{C}, \mathrm{H}, \mathrm{N})$ was performed using a Heraeus Elemental Analyzer CHN-O-Rapid (Elementar-Analysensysteme, Gmbh, West Germany). A Metrohm 757 VA computrace instrument was employed to obtain cyclic voltammograms in acetonitrile at room temperature $\left(25^{\circ} \mathrm{C}\right)$ using $0.1 \mathrm{M}$ tetra-n-butylammonium hexafluorophosphate (TBAHFP) solution as supporting electrolyte. A platinum electrode was used as the auxiliary electrode and $\mathrm{Ag} / \mathrm{AgCl}$ electrode as working electrode.

2.1. Synthesis of the Complexes. $\mathrm{Ru}(\mathrm{ttp}) \mathrm{Cl}_{3}$ was synthesized following a similar procedure as described for $\mathrm{Ru}\left(\right.$ terpy) $\mathrm{Cl}_{3}$ [40]. The reaction of $\mathrm{Ru}(\mathrm{ttp}) \mathrm{Cl}_{3}$ with o-phenylenediamine (opda) and 4,5-dimethyle-o-phenylenediamine gave $[\mathrm{Ru}(\mathrm{ttp})(\mathrm{bqdi}) \mathrm{Cl}] \mathrm{PF}_{6}(\mathbf{1})$ and $[\mathrm{Ru}(\mathrm{ttp})(4, \mathrm{~d}-\mathrm{diMe}-\mathrm{bqdi}) \mathrm{Cl}]$ $\mathrm{PF}_{6}(2)$, respectively.

2.2. Preparation of $\left[\mathrm{Ru}(t \mathrm{tt})(b q d i) \mathrm{Cl} \mathrm{PF}_{6} \cdot 2 \mathrm{H}_{2} \mathrm{O}\right.$ (1). [Ru (ttp) $\left.\mathrm{Cl}_{3}\right](0.7 \mathrm{~g}, 1.32 \mathrm{mmol})$, o-phenylenediamine $(0.18 \mathrm{~g}$, $1.67 \mathrm{mmol})$, and $\mathrm{NEt}_{3}(0.5 \mathrm{~mL}, 3.1 \mathrm{mmol})$ were dissolved in $100 \mathrm{~mL}$ of ethanol/water $(3: 1)$ and were refluxed for 4 hours. $0.5 \mathrm{~g}$ of $\mathrm{LiCl}$ was then added, and the reaction mixture was refluxed for a further $30 \mathrm{~min}$. The color of the solution turned to purple. The solvent of the reaction was evaporated to about $20 \mathrm{~mL}$, and $1 \mathrm{~g}$ of $\mathrm{NH}_{4} \mathrm{PF}_{6}$ was added. After the addition of $300 \mathrm{~mL}$ of water, the dark precipitate was filtered off and washed thoroughly with ice-cold water and diethyl ether and air dried. It was then purified on an alumina (neutral) column. The purple target complex was obtained by elution with $\mathrm{CH}_{3} \mathrm{CN} /$ Toluene $(1: 1)$. Evaporation of the solvent under reduced pressure gave analytically pure target compounds. Yield: $220 \mathrm{mg}, 25 \% .{ }^{1}$ HNMR: 13.65 (s, $1 \mathrm{H}$ ), 11.45 (s, 1H), 9.42-6.99 (m, 18p), 2.48 (s, 3p); IR $\left(\mathrm{cm}^{-1}\right)$ : 3447, 3302, 842; UV-Vis, $\lambda_{\max } / \mathrm{CH}_{3} \mathrm{CN}, \mathrm{nm}\left(\varepsilon, \mathrm{M}^{-1} \mathrm{~cm}^{-1}\right)$ : 490 (22600), 310 (59700), 284.5 (54700). Anal. calcd. for $\mathrm{C}_{28} \mathrm{H}_{27} \mathrm{~N}_{5} \mathrm{ClF}_{6} \mathrm{PO}_{2} \mathrm{Ru}$ : C: 45.1; H: 3.6; N: 9.4; found: C: 45.2; H: 3.8; N: 9.2.

\subsubsection{Preparation of $[R u(t t p)(4, d-d i M e-b q d i) C l] P F_{6}$ (2).} Complex two was synthesized following the same procedure as described for (1) except 4,5-dimethyle-ophenylenediamine was used instead of o-phenylenediamine. Yield: $253 \mathrm{mg}, 26 \%{ }^{1} \mathrm{HNMR}$ : $14.03(\mathrm{~s}, 1 \mathrm{H}), 11.50(\mathrm{~s}, 1 \mathrm{H})$, 9.46-6.70 (m, 16P), $2.40(\mathrm{~s}, 3 \mathrm{H}), 2.21(\mathrm{~s}, 3 \mathrm{H}), 2.07(\mathrm{~s}, 3 \mathrm{H})$. IR $\left(\mathrm{cm}^{-1}\right): 3448,3301,840$; UV-Vis, $\lambda_{\max } / \mathrm{CH}_{3} \mathrm{CN}, \mathrm{nm}(\varepsilon$, $\mathrm{M}^{-1} \mathrm{~cm}^{-1}$ ): 529.7 (39600), 237.7 (37900), 284.1 (46600). Anal. calcd. for $\mathrm{C}_{30} \mathrm{H}_{27} \mathrm{~N}_{5} \mathrm{ClF}_{6} \mathrm{PRu}$ : C: 48.7; $\mathrm{H}: 3.7 ; \mathrm{N}$ : 9.5; found: C: 48.6; H: 3.9; N: 9.3.

\subsection{Biological Studies}

2.3.1. Melting Temperature Analysis. The temperature at which $50 \%$ of the double helix denatures into single strand DNA is known as $T_{m}$. It is shown that the interaction of small molecules with DNA increases the $T_{m}[41,42]$. Two $\mathrm{mL}$ of the solutions containing $10 \mu \mathrm{L}$ of DNA solution, $10 \mu \mathrm{L}$ of $3 \mu \mathrm{M}$ complex (1) or (2) and $1980 \mu \mathrm{L}$ of tris-buffer were prepared. The temperature of the solutions was increased gradually and the absorbance at $260 \mathrm{~nm}$ was monitored. $T_{m}$ values were obtained by plotting the absorbance versus temperature. Similar experiments were done for the control solution containing $10 \mu \mathrm{L}$ of DNA solution and $1990 \mu \mathrm{L}$ of trisbuffer solution.

\subsubsection{Determination of Minimum Inhibitory Concentrations} (MIC). In order to further investigate the interaction of the two newly synthesized complexes with E. coli bacteria, anti-bacterial tests were also performed. The tests were performed by microdilution assays, and minimum inhibitory concentration (MIC) values, defined as the minimal concentration of the complexes which prevents the growth of the microorganisms, were obtained by the microdilution broth method, as recommended by NCCLS standards [43]. The complexes were first dissolved in DMSO and were diluted to $200 \mu \mathrm{g} \mathrm{mL}^{-1}$. Serial twofold dilutions to about $1.6 \mu \mathrm{g} \mathrm{mL}^{-1}$ were performed in sterile tubes. A suspension of the microorganism was added to each dilution in a $1: 1$ ratio. The growth or lack of the E. coli bacteria was visually determined after $48 \mathrm{~h}$ of incubation at $37^{\circ} \mathrm{C}$. The lowest concentration at which 
TABLE 1: Electrochemical data for Ru complexes in acetonitrile.

\begin{tabular}{lcccccccc}
\hline & \multicolumn{3}{c}{$(\mathbf{1})$} & & \multicolumn{3}{c}{ (2) } & \\
& $E^{\mathrm{c}}(\mathrm{mV})$ & $E^{\mathrm{a}}(\mathrm{mV})$ & $\Delta E(\mathrm{mV})$ & $E^{0}(\mathrm{mV})$ & $E^{\mathrm{c}}(\mathrm{mV})$ & $E^{\mathrm{a}}(\mathrm{mV})$ & $\Delta E(\mathrm{mV})$ & $E^{0}(\mathrm{mV})$ \\
\hline $\mathrm{Ru}^{\mathrm{II}} \mathrm{NIL} / \mathrm{Ru}^{\mathrm{III}} \mathrm{NIL}$ & 1510 & 1590 & 80 & 1550 & 1390 & 1490 & 100 & 1440 \\
$\mathrm{Ru}^{\mathrm{II}} \mathrm{NIL} / \mathrm{Ru}^{\mathrm{II}} \mathrm{NIL}$ & -850 & -998 & 148 & -924 & -1631 & - & - & -1220 \\
$\mathrm{Ru}^{\mathrm{II}} \mathrm{NIL} / \mathrm{Ru}^{\mathrm{II}} \mathrm{NIL}^{\mathrm{Red}}$ & -1850 & -1990 & 140 & -1920 & -1582 & -1493 & 89 & -1545 \\
\hline
\end{tabular}

Data are for $10^{-3} \mathrm{M}$ solutions of the complexes in acetonitrile in presence of $0.1 \mathrm{M}$ of TBAHFP as supporting electrolyte. $E^{\mathrm{c}}: E$ cathodic; $E^{\mathrm{a}}: E$ anodic.

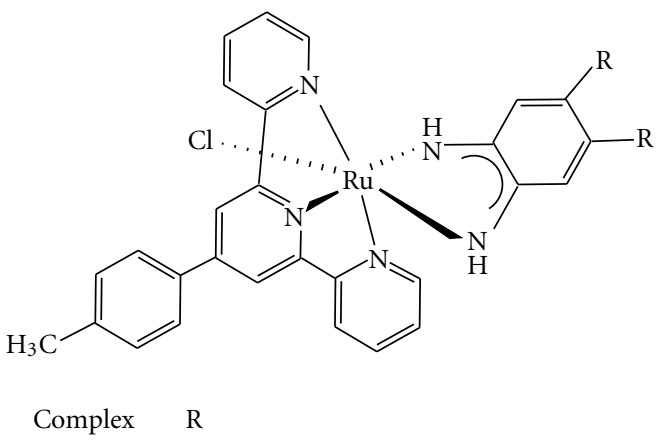

(1) $\mathrm{H}$

(2) $\mathrm{CH}_{3}$

FIGURE 1: Structure of the complexes (1) and (2).

no visible growth was seen was chosen as the MICs. The experiments were repeated for three times. Besides, control experiments with DMSO were also done.

\section{Results and Discussions}

3.1. Synthesis of the Complexes. The complexes were readily prepared by the equimolar reaction between $\mathrm{Ru}(\mathrm{ttp}) \mathrm{Cl}_{3}$ and appropriate derivative of o-phenylenediamine in the presence of $\mathrm{NEt}_{3}$ as base and ethanol/water (3/1) as solvent (Figure $1)$. The complexes were purified by column chromatography. Alumina was employed as the stationary phase, and $\mathrm{CH}_{3} \mathrm{CN} /$ Toluene $(1: 1)$ was used as the eluent. The complexes were isolated as hexafluorophosphate salt in good yields.

\subsection{Spectroscopic and Electrochemical Determination of the} Complexes. In the ${ }^{1} \mathrm{HNMR}$ spectra of the diamagnetic $\mathrm{Ru}{ }^{\mathrm{II}}$ complexes, the presence of two singlets at around 14 and $11 \mathrm{ppm}$ is indicative of the formation of two benzoquinone type NHs. As it could be seen from Figure 1, these two protons are not equivalent; one of them is trans to $\mathrm{Cl}$ ligand while the other one is trans to the nitrogen atom of the ttp ligand. Aromatic protons of ttp and those of o-benzoquinonediimine ligands also appear in the region of 6.5-9.5 as multiplets. Protons of the $\mathrm{CH}_{3}$ group of ttp appear in the region of the aliphatic protons at $2.48 \mathrm{ppm}$ and $2.40 \mathrm{ppm}$ for (1) and (2), respectively. For complex (2), two sets of signals at the region of the aliphatic protons are also observed which are consistent with the two $\mathrm{CH}_{3}$ substituents of the 4,5dimethyl-o-benzoquinonediimine ligand. In the IR spectra

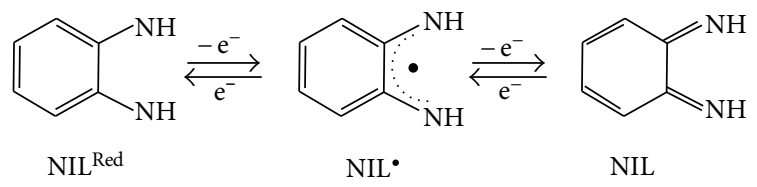

Figure 2: The coordination modes of the NIL ligands.

of the complexes, the signals at around 3400 and $3300 \mathrm{~cm}^{-1}$ are indicative of $\mathrm{NHs}$ of benzoquinonediimine ligands and the peak at around $840 \mathrm{~cm}^{-1}$ is due to uncoordinated $\mathrm{PF}_{6}$. The absorption spectra of these complexes are typical of the ruthenium polypyridyl complexes. The intense UV bands at $310,284.5 \mathrm{~nm}$ for complex (1) and 237.7, $284 \mathrm{~nm}$ for complex (2) are assignable to $\pi \rightarrow \pi^{*}$ transition of the ligands. Metal to ligand charge transfer (MLCT) transitions are observed as slightly broad bands in the visible region at 490 and $529.7 \mathrm{~nm}$ for complexes (1) and (2), respectively. The presence of two-electron donating methyl substituents on the o-benzoquinonediimine ligand of complex (2) has resulted in considerable red shift in the MLCT transition. As it could be seen from Figure 2, the coordination mode of o-phenylenediamine ligand could be one of three forms. Since the electronic spectra of these complexes do not present absorptions at wavelengths higher than $600 \mathrm{~nm}$, it could be rationalized that o-phenylenediamine ligands are not in their semiquinonoid forms (Figures 1 and 2) [44]. Comparison of our data with those of the literature reports [45-48], especially $[49,50]$, shows that o-phenylenediamine ligands are coordinated in the form of their benzoquinonediimine coordination mode.

Electrochemical studies also support this conclusion. The electrochemical behavior of the complexes was studied by means of cyclic voltammetry in acetonitrile solution. Voltammograms were obtained at room temperature $\left(25^{\circ} \mathrm{C}\right)$ using $0.1 \mathrm{M}$ tetra-n-butylammonium hexafluorophosphate (TBAHFP) solution as supporting electrolyte. A platinum electrode was used as the auxiliary electrode and $\mathrm{Ag} / \mathrm{AgCl}$ electrode as working electrode. Figure 3 shows the $\mathrm{CV}$ of complex (1). The results for both complexes are collected in Table 1. As it could be seen from Figure 3, the peak observed in the oxidation region at $1.55 \mathrm{~V}$ versus NHE could be attributed to the process of $\mathrm{Ru}^{\mathrm{II}}$ (bqdi)/Ru ${ }^{\mathrm{III}}$ (bqdi). Two peaks are also observed in the reduction region, -0.92 and $-1.92 \mathrm{~V}$ versus NHE, respectively. The first peak is assigned to the process of $\mathrm{Ru}^{\mathrm{II}}$ (bqdi)/Ru ${ }^{\mathrm{II}}$ (s-bqdi) reduction in which 


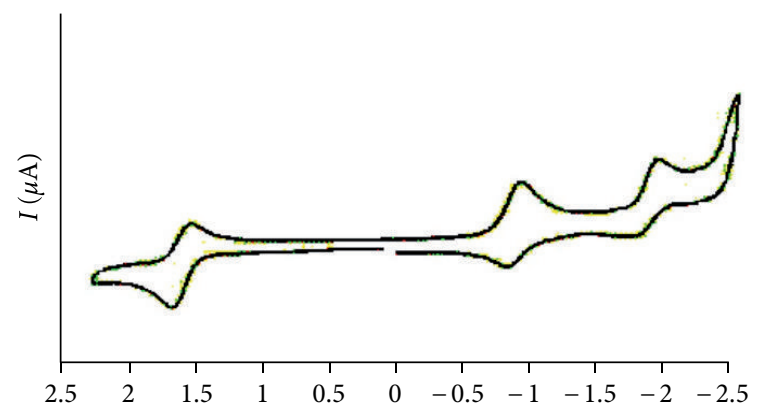

Figure 3: Cyclic voltammogram of $10^{-3} \mathrm{M}$ solution of complex (1) in acetonitrile in the presence of $0.1 \mathrm{M}$ of TBAHFP as supporting electrolyte.

bqdi (benzoquinonediimine) NIL ligand is reduced to its sbqdi (semi-benzoquinonediimine) $\mathrm{NIL}^{\bullet}$. The second peak is also a ligand centered reduction in which s-bqdi is reduced to NIL ${ }^{\text {Red }}$. For complex (2), the oxidation peak is observed at $1.44 \mathrm{~V}$ versus NHE which is shifted to less positive values compared to complex (1). This is also assignable to the metal-centered oxidation, $\mathrm{Ru}^{\mathrm{II}}$ (4,5-diMebqdi)/Ru ${ }^{\mathrm{III}}$ (4,5diMebqdi) [50]. This shift in the redox potential is due to the presence of two-electron donating methyl groups on the ancillary ligand. In the reduction region, the anodic peak of the first reduction process is not observed which shows an irreversible process. But the second reduction is reversible and is observed at $-1.54 \mathrm{~V}$ versus NHE. Since these two peaks are NIL ligand centered reductions, they are more sensitive to the presence of two methyl groups on this ligand. The two signals are shifted to more positive values which is the direct consequence of the presence of the electron donating methyl substituents.

\subsection{Biological Studies}

3.3.1. $T_{m}$ Analysis. The melting curves of DNA alone and DNA-Ru complex mixtures are shown in Figure 4. $T_{m}$ experiments for the DNA alones showed a $T_{m}$ value of $73 \pm 0.2^{\circ} \mathrm{C}$ which has increased upon the interaction with $\mathrm{Ru}$ complexes. The $T_{m}$ of the DNA increased $1^{\circ} \mathrm{C}$ by the interaction with complex (1) and $4^{\circ} \mathrm{C}$ with complex (2). It is shown that the groove binders have $\Delta T_{m}$ values similar to our observed values, and hence it could be concluded that the groove binding is the major interaction by these $\mathrm{Ru}$ complexes [22, 44]. It is also shown that the presence of electron donating substituents on the coordinated ligands increases the DNA-binding ability of Ru complexes [47]. Similar results are observed for our complex (2). The higher $\Delta T_{m}$ for (2) is probably caused by the more positive surface charge of the complex which increases the binding ability of the complex with donor groups of the DNA.

Similar experiments, with other dosages of the complexes, were also performed. Figure 5 shows the results for 20 and 50 dosages of (2) (total volume of $2 \mathrm{~mL}$ and constant dosage of DNA; $10 \mu \mathrm{L})$.

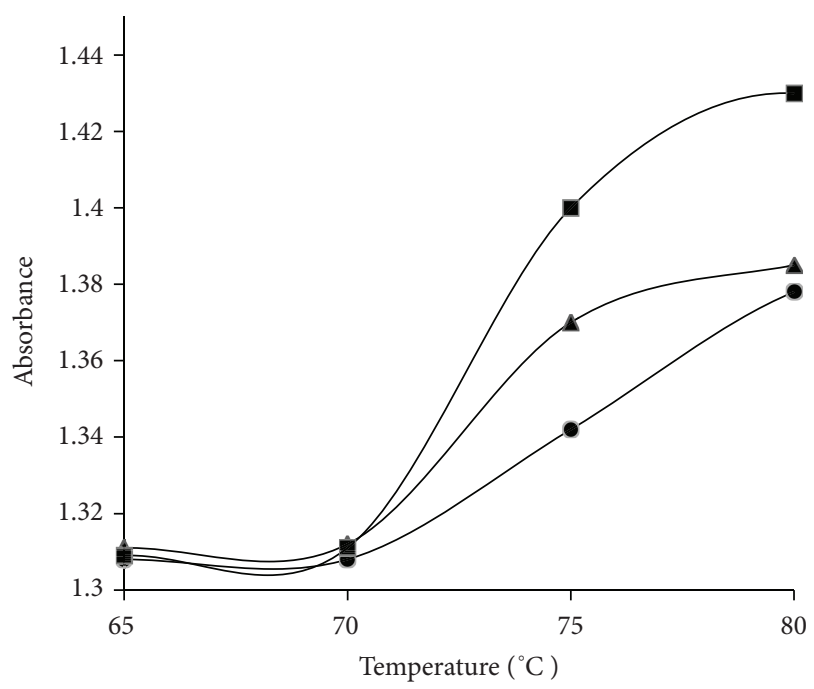

Figure 4: The melting curves of E. coli GM109 DNA at $260 \mathrm{~nm}$ in the absence and presence of complexes. DNA alone ( $\boldsymbol{\square})$, with $10 \mu \mathrm{L}$

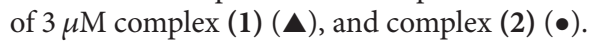

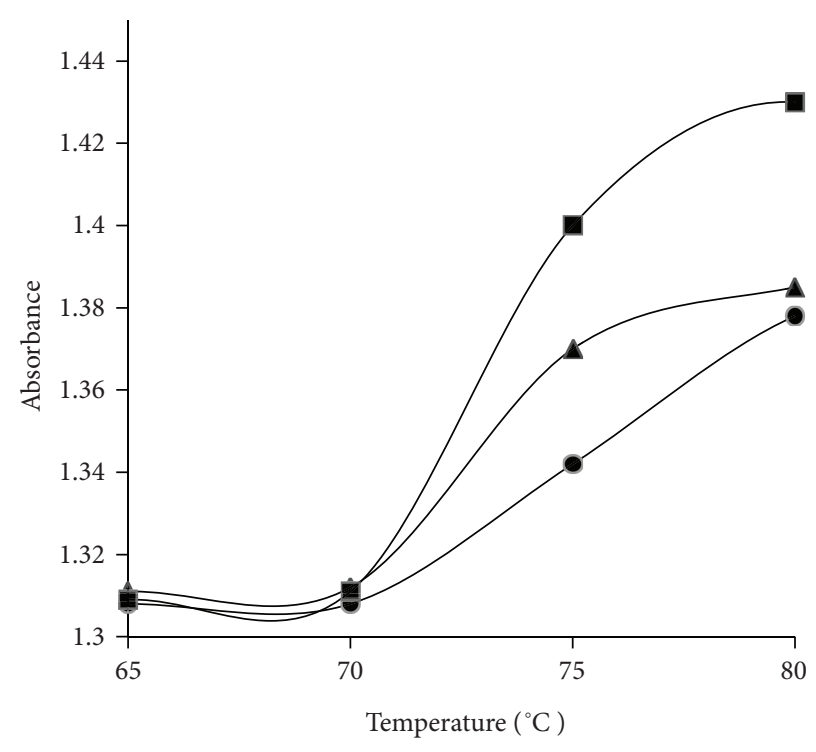

FIGURE 5: The melting curves of E. coli GM109 DNA at $260 \mathrm{~nm}$ in the absence and presence of different dosages of complex (2). DNA alone ( $), 20 \mu \mathrm{L}(\mathbf{\Delta})$, and $50 \mu \mathrm{L}(\bullet)$ of $3 \mu \mathrm{M}$ of (2).

As it could be seen from Figure 5, no significant change was observed for the $\Delta T_{m}$ of the DNA by increasing the dosage of the complexes, and $10 \mu \mathrm{L}$ of the complexes was chosen as the optimized dosage.

3.3.2. Antibacterial Studies. The antimicrobial activity of the two complexes was studied by microdilution method, and our results show that both complexes inhibited the growth of the E. coli bacteria very effectively [51-55]. The MIC values for both complexes were determined to be $12.5 \mu \mathrm{g} \mathrm{mL}^{-1}$. These values are comparable with standard compounds such as Ampicillin in our conditions. 


\section{Conclusion}

Two new ruthenium polypyridine complexes with noninnocent orthobenzoquinonediimine type ligands were synthesized and characterized. Electrochemical and spectroscopic properties of the complexes were also investigated. The $\mathrm{Ru}^{\text {II }}$ (4,5-diMebqdi)/Ru ${ }^{\text {III }}$ (4,5-diMebqdi) oxidation peak of complex (2) was shifted to less positive values compared to complex (1) which was attributed to the presence of the electron donating methyl groups on the non-innocent ligand. The interaction of the complexes with E. coli GM109 DNA was investigated by means of $T_{m}$ analysis. The results show that complex (2) increases the $T_{m}$ more than (1) which means that it has greater interaction with the DNA. Antibacterial studies also show that these complexes are effective against the studied microorganism.

\section{References}

[1] T. Naota, H. Takaya, and S. L. Murahashi, "Rutheniumcatalyzed reactions for organic synthesis," Chemical Reviews, vol. 98, no. 7, pp. 2599-2660, 1998.

[2] Z. Zhao, M. Wang, L. Cui, J. He, D. Yu, and Y. Tian, "Semiconducting superhard ruthenium monocarbide," Journal of Physical Chemistry C, vol. 114, no. 21, pp. 9961-9964, 2010.

[3] M. Al-Noaimi, G. P. A. Yap, and R. J. Crutchley, "Outer sphere perturbation of delocalized mixed-valence complexes," Inorganic Chemistry, vol. 43, pp. 1773-1784, 2004.

[4] G. L. Xu, R. J. Crutchley, M. C. DeRosa et al., "Strong electronic couplings between ferrocenyl centers mediated by bis-ethynyl/butadiynyl diruthenium bridges," Journal of the American Chemical Society, vol. 127, no. 38, pp. 13354-13363, 2005.

[5] D. A. Boyd, R. J. Crutchley, P. E. Fanwick, and T. Ren, "FcFc electronic interaction through equatorial pathways of a diruthenium core," Inorganic Chemistry, vol. 49, no. 4, pp. 1322-1324, 2010.

[6] L. Bijeire, B. Elias, J. P. Souchard et al., "Photoelectron transfer processes with ruthenium(II) polypyridyl complexes and $\mathrm{Cu} / \mathrm{Zn}$ superoxide dismutase," Biochemistry, vol. 45, no. 19, pp. 6160-6169, 2006.

[7] H. Durr and S. Bossmann, "Ruthenium polypyridine complexes. On the route to biomimetic assemblies as models for the photosynthetic reaction center," Accounts of Chemical Research, vol. 34, no. 11, pp. 905-917, 2011.

[8] R. Noyori and S. Hashiguchi, "Asymmetric transfer hydrogenation catalyzed by chiral ruthenium complexes," Accounts of Chemical Research, vol. 30, pp. 97-102, 1977.

[9] J. J. Concepcion, J. W. Jurss, M. K. Brennaman et al., "Making oxygen with ruthenium complexes," Accounts of Chemical Research, vol. 42, no. 12, pp. 1954-1965, 2009.

[10] J. R. Winkler and H. B. Gray, "Electron transfer in rutheniummodified proteins," Chemical Reviews, vol. 92, no. 3, pp. 369-379, 1992.

[11] R. E. Morris, R. E. Aird, P. Del Socorro Murdoch et al., "Inhibition of cancer cell growth by ruthenium(II) arene complexes," Journal of Medicinal Chemistry, vol. 44, no. 22, pp. 3616-3621, 2001.
[12] C. A. Vock, W. H. Ang, C. Scolaro et al., "Development of ruthenium antitumor drugs that overcome multidrug resistance mechanisms," Journal of Medicinal Chemistry, vol. 50, no. 9, pp. 2166-2175, 2007.

[13] M. G. Mendoza-Ferri, C. G. Hartinger, M. A. Mendoza et al., "Transferring the concept of multinuclearity to ruthenium complexes for improvement of anticancer activity," Journal of Medicinal Chemistry, vol. 52, no. 4, pp. 916-925, 2009.

[14] G. A. McLachlan, J. G. Muller, S. E. Rokita, and C. J. Burrows, "Metal-mediated oxidation of guanines in DNA and RNA: a comparison of cobalt(II), nickel(II) and copper(II) complexes," Inorganica Chimica Acta, vol. 251, no. 1-2, pp. 193-199, 1996.

[15] R. Indumathy, M. Kanthimathi, T. Weyhermuller, and B. U. Nair, "Cobalt complexes of terpyridine ligands: crystal structure and nuclease activity," Polyhedron, vol. 27, no. 17, pp. 3443-3450, 2008.

[16] J. C. Genereux and J. K. Barton, "Mechanisms for DNA charge transport," Chemical Reviews, vol. 110, no. 3, pp. 1642-1662, 2010.

[17] M. Pitie and G. Pratviel, "Activation of DNA carbon-hydrogen bonds by metal complexes," Chemical Reviews, vol. 110, pp. 1018-1059, 2010.

[18] R. E. Mewis and S. J. Archibald, "Biomedical applications of macrocyclic ligand complexes," Coordination Chemistry Reviews, vol. 254, pp. 1686-1712, 2010.

[19] L. F. Tan and H. Chao, "DNA-binding and photocleavage studies of mixed polypyridyl ruthenium(II) complexes with calf thymus DNA," Inorganica Chimica Acta, vol. 360, no. 6, pp. 2016-2022, 2007.

[20] Y. Nakabayashi, H. Inada, Y. Minoura, N. Iwamoto, and O. Yamauchi, "Effects of flexible bridging ligands on DNAbinding of dinuclear ruthenium(II)-2,2' -bipyridine complexes," Inorganica Chimica Acta, vol. 362, no. 3, pp. 869-877, 2009.

[21] H. J. Yu, H. Chao, L. Jiang, L. Y. Li, S. M. Huang, and L. N. Ji, "Single oxygen-mediated DNA photocleavage of a dibithiazolyl ruthenium(II) complex $\left[\mathrm{Ru}(\mathrm{btz})_{2}(\mathrm{dppz})\right]^{2+}$," Inorganic Chemistry Communications, vol. 11, pp. 553-556, 2008.

[22] G. Sathyaraj, T. Weyhermuller, and B. U. Nair, "Synthesis, characterization and DNA binding studies of new ruthenium(II)bisterpyridine complexes," European Journal of Medicinal Chemistry, vol. 45, pp. 284-291, 2010.

[23] A. Sigel and H. Sigel, Metal Ions in Biological Systems, vol. 33, Marcel Dekker, New York, NY, USA, 1996.

[24] K. E. Erkkila, D. T. Odom, and J. K. Barton, "Recognition and reaction of metallointercalators with DNA," Chemical Reviews, vol. 99, no. 9, pp. 2777-2795, 1999.

[25] I. Kostova, "Ruthenium complexes as anticancer agents," Current Medicinal Chemistry, vol. 13, pp. 1085-1107, 2006.

[26] C. S. Allardyce and P. J. Dyson, "Ruthenium in medicine: current clinical uses and future prospects," Platinum Metals Review, vol. 45, no. 2, pp. 62-69, 2001.

[27] M. J. Clarke, "Ruthenium metallopharmaceuticals," Coordination Chemistry Reviews, vol. 236, no. 1-2, pp. 209-233, 2003.

[28] C. G. Hartinger, S. Zorbas-Seifried, M. A. Jakupec, B. Kynast, H. Zorbas, and B. K. Keppler, "From bench to bedside-preclinical and early clinical development of the anticancer agent indazolium trans-[tetrachlorobis(1H-indazole)ruthenate(III)] (KP1019 or FFC14A)," Journal of Inorganic Biochemistry, vol. 100, no. 5-6, pp. 891-904, 2006.

[29] M. S. Deshpande, A. A. Kumbhar, and A. S. Kumbhar, "Hydrolytic cleavage of DNA by a ruthenium(II) polypyridyl complex," Inorganic Chemistry, vol. 46, pp. 5450-5452, 2007. 
[30] C. Bazzicalupi, A. Bencini, A. Bianchi et al., "A zinc(II)based receptor for ATP binding and hydrolysis," Chemical Communications, no. 20, pp. 2630-2632, 2005.

[31] M. J. Clarke, "Ruthenium metallopharmaceuticals," Coordination Chemistry Reviews, vol. 232, no. 1-2, pp. 69-93, 2002.

[32] L. N. Ji, X. H. Zou, and J. G. Liu, "Shape- and enantioselective interaction of $\mathrm{Ru}(\mathrm{II}) / \mathrm{Co}(\mathrm{III})$ polypyridyl complexes with DNA," Coordination Chemistry Reviews, vol. 216-217, pp. 513-536, 2001.

[33] X. L. Hong, H. Chao, L. J. Lin et al., "Synthesis, characterization, and DNA-binding properties of the ruthenium(II) complexes $[\mathrm{Ru}($ dipn $)(\mathrm{dptp})]\left(\mathrm{ClO}_{4}\right)_{2} \quad$ and $\quad[\mathrm{Ru}(\mathrm{dipn})(\mathrm{pat})]\left(\mathrm{ClO}_{4}\right)_{2}$ (dipn $=N$-(3-aminpropyl)propane-1,3-diamine; $\mathrm{dptp}=2$ (5,6-diphenyl-1,2,4-triazin-3-yl)-1,10-phenanthroline; pat=9(1,10-phenanthrolin-2-yl)acenaphtho[1,2-e][1,2,4]triazine)," Helvetica Chimica Acta, vol. 87, no. 5, pp. 1180-1193, 2004.

[34] P. U. Maheswari and M. Palaniandavar, "DNA binding and cleavage activity of $[\mathrm{Ru}(\mathrm{NH} 3) 4$ (diimine) $] \mathrm{Cl} 2$ complexes," Inorganica Chimica Acta, vol. 357, no. 4, pp. 901-912, 2004.

[35] H. Xu, K. C. Zheng, Y. Cheng et al., "Effects of ligand planarity on the interaction of polypyridyl Ru(II) complexes with DNA," Journal of the Chemical Society, Dalton Transactions, no. 11, pp. 2260-2268, 2003.

[36] P. U. Maheswari, V. Rajendiran, M. Palaniandavar, R. Parthasarathi, and V. Subramanian, "Synthesis, characterization and DNA-binding properties of rac- $[\mathrm{Ru}(5,6-$ $\mathrm{dmp}) 2(\mathrm{dppz})]^{2+}$-Enantiopreferential DNA binding and co-ligand promoted exciton coupling," Journal of Inorganic Biochemistry, vol. 100, no. 1, pp. 3-17, 2006.

[37] R. Liegghio, P. G. Potvin, and A. B. P. Lever, "2,6dipyrazinylpyridines and their ruthenium(II) complexes: a new polynucleating ligand family," Inorganic Chemistry, vol. 40, no. 22, pp. 5485-5486, 2001.

[38] F. B. Dean, J. R. Nelson, T. L. Giesler, and R. S. Lasken, "Rapid amplification of plasmid and phage DNA using Phi29 DNA polymerase and multiply-primed rolling circle amplification," Genome Research, vol. 11, no. 6, pp. 1095-1099, 2001.

[39] K. Watanabe, T. Oshima, K. Iijima, Z. Yamaizumi, and S. Nishimura, "Purification and thermal stability of several amino acid-specific tRNAs from an extreme thermophile, Thermus thermophilus HB8," The Journal of Biochemistry, vol. 87, no. 1, pp. $1-13,1980$.

[40] M. Al-Noaimi, G. P. A. Yap, and R. J. Crutchley, "Outer sphere perturbation of delocalized mixed-valence complexes," Inorganic Chemistry, vol. 43, no. 5, pp. 1770-1778, 2004.

[41] M. Cusumando and A. Giannetto J, "The interaction of mixedligand square-planar complexes with calf thymus DNA," Journal of Inorganic Biochemistry, vol. 65, pp. 137-144, 1997.

[42] G. A. Neyhart, N. Grover, S. R. Smith et al., "Binding and kinetics studies of oxidation of DNA by oxoruthenium (IV)," Journal of the American Chemical Society, vol. 115, no. 11, pp. 4423-4428, 1993.

[43] National Committee for Clinical and Laboratory Standards, in Method for Dilution Antimicrobial Susceptibility Tests for Bacteria that Grow Aerobically, pp. S.100-S.157, NCCLS, Villanova, Italy, Approved Standard 4th edition, 1997.

[44] V. I. Ivanov, L. E. Minchenkova, A. K. Schyolkina, and A. I. Poletayev, "Different conformations of double-stranded nucleic acid in solution as revealed by circular dichroism.," Biopolymers-Peptide Science Section, vol. 12, no. 1, pp. 89-110, 1973.

[45] Y. Liu, C. G. Liu, S. L. Sun, G. C. Yang, and Y. Q. Qiu, "Redox-switching second-order nonlinear optical responses of
$\mathrm{N}^{\wedge} \mathrm{N}^{\wedge} \mathrm{N}$ ruthenium complexes," Computational and Theoretical Chemistry, vol. 979, pp. 112-118, 2012.

[46] Q. X. Zhou, F. Yang, W. H. Lei et al., "Ruthenium(II) terpyridyl complexes exhibiting DNA photocleavage: the role of the substituent on monodentate ligand," The Journal of Physical Chemistry B, vol. 113, pp. 11521-11526, 2009.

[47] E. Grueso, G. López-Pérez, M. Castellano, and R. PradoGotor, "Thermodynamic and structural study of phenanthroline derivative ruthenium complex/DNA interactions: probing partial intercalation and binding properties," Journal of Inorganic Biochemistry, vol. 106, no. 1, pp. 1-9, 2012.

[48] S. Maji, S. Patra, S. Chakraborty et al., "Valence-state distribution in the ruthenium $o$-quinonoid systems $\left[\mathrm{Ru}(\operatorname{trpy})-(\mathrm{Cl})\left(\mathrm{L}^{1}\right)\right]^{+}$and $\left[\mathrm{Ru}(\operatorname{trpy})(\mathrm{Cl})\left(\mathrm{L}^{2}\right)\right]^{+} \quad\left(\mathrm{L}^{1}=o-\right.$ iminobenzoquinone, $\mathrm{L}^{2}=o$-diiminobenzoquinone; trpy $=2,2^{\prime}: 6^{\prime}, 2^{\prime \prime}$-terpyridine)," European Journal of Inorganic Chemistry, no. 2, pp. 314-323, 2007.

[49] N. Gupta, N. Grover, G. A. Neyhart, P. Singh, and H. H. Thorp, "Synthesis and properties of new DNA cleavage agents based on oxoruthenium(IV)," Inorganic Chemistry, vol. 32, no. 3, pp. 310-316, 1993.

[50] J. L. Boyer, J. Rochford, M. K. Tsai, J. T. Muckerman, and E. Fujita, "Ruthenium complexes with non-innocent ligands: electron distribution and implications for catalysis," Coordination Chemistry Reviews, vol. 254, no. 3-4, pp. 309-330, 2010.

[51] J. Liu, R. Cao, Q. Wu et al., "Synthesis and antibacterial evaluation of novel 4 -alkyl substituted phenyl $\beta$-aldehyde ketone derivatives," European Journal of Medicinal Chemistry, vol. 44, no. 4, pp. 1737-1744, 2009.

[52] V. Mahalingam, N. Chitrapriya, F. R. Fronczek, and K. Natarajan, "New Ru(II)-dmso complexes with heterocyclic hydrazone ligands towards cancer chemotherapy," Polyhedron, vol. 27, no. 7, pp. 1917-1924, 2008.

[53] V. Mahalingam, N. Chitrapriya, M. Zeller, and K. Natarajan, "Ru(II)-DMSO complexes containing aromatic and heterocyclic acid hydrazides: structure, electrochemistry and biological activity," Polyhedron, vol. 28, no. 8, pp. 1532-1540, 2009.

[54] V. Mahalingam, N. Chitrapriya, F. R. Fronczek, and K. Natarajan, "New Ru(II)-DMSO complexes of ON/SN chelates: synthesis, behavior of Schiff bases towards hydrolytic cleavage of $\mathrm{CN}$ bond, electrochemistry and biological activities," Polyhedron, vol. 29, no. 18, pp. 3363-3371, 2010.

[55] P. Gameiro, C. Rodrigues, T. Baptista, I. Sousa, and B. de Castro, "Solution studies on binary and ternary complexes of copper(II) with some fluoroquinolones and 1,10-phenanthroline: antimicrobial activity of ternary metalloantibiotics," International Journal of Pharmaceutics, vol. 334, no. 1-2, pp. 129-136, 2007. 

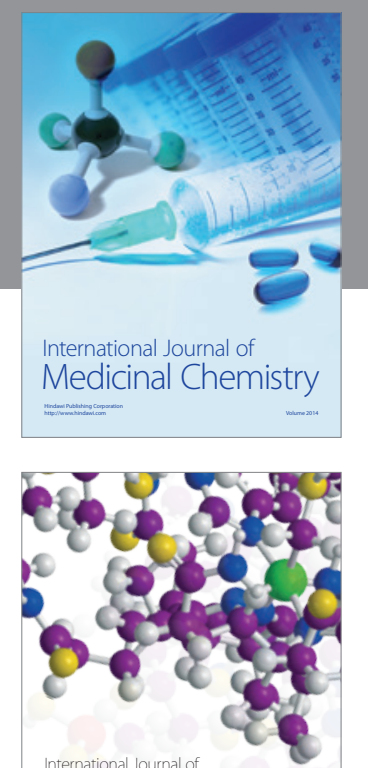

\section{Carbohydrate} Chemistry

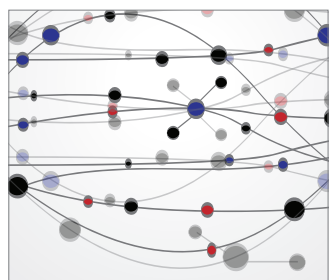

The Scientific World Journal
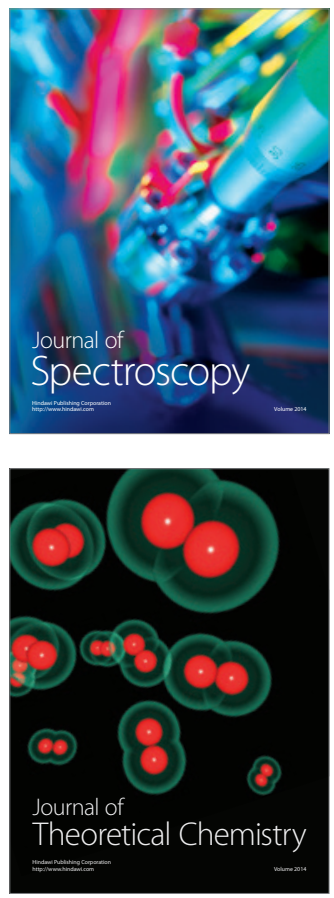
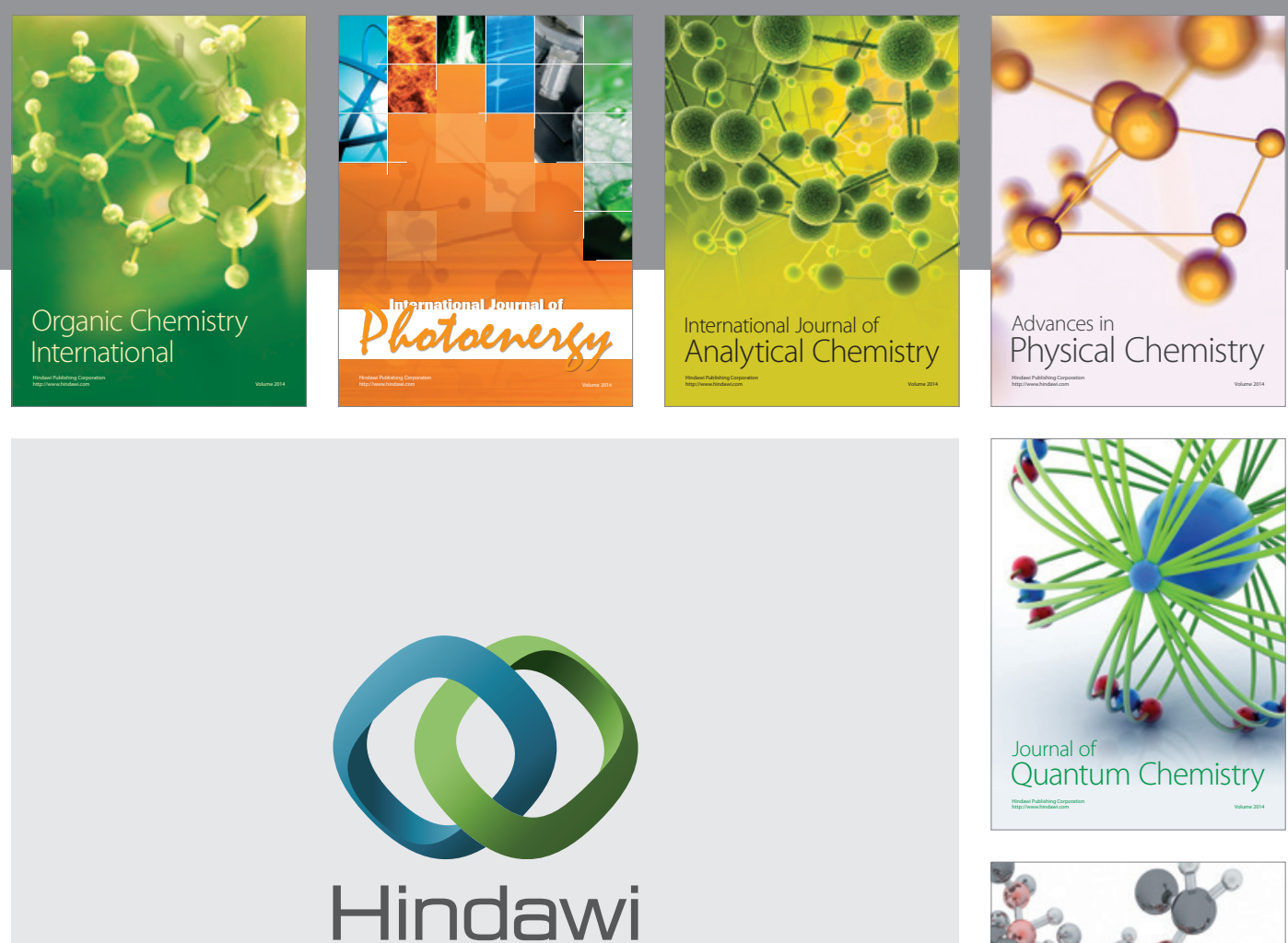

Submit your manuscripts at

http://www.hindawi.com

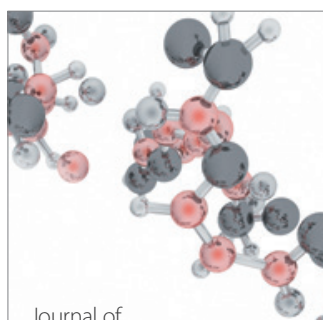

Analytical Methods

in Chemistry

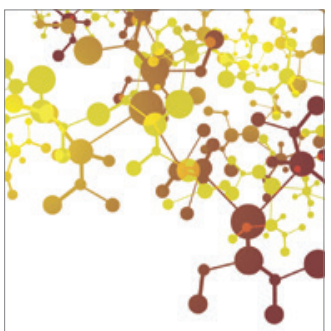

Journal of

Applied Chemistry

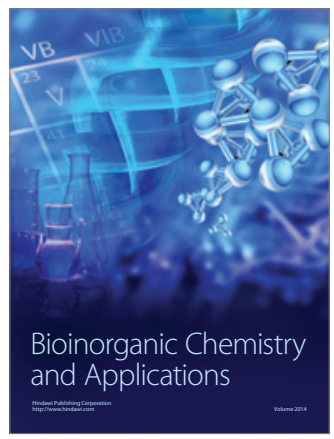

Inorganic Chemistry
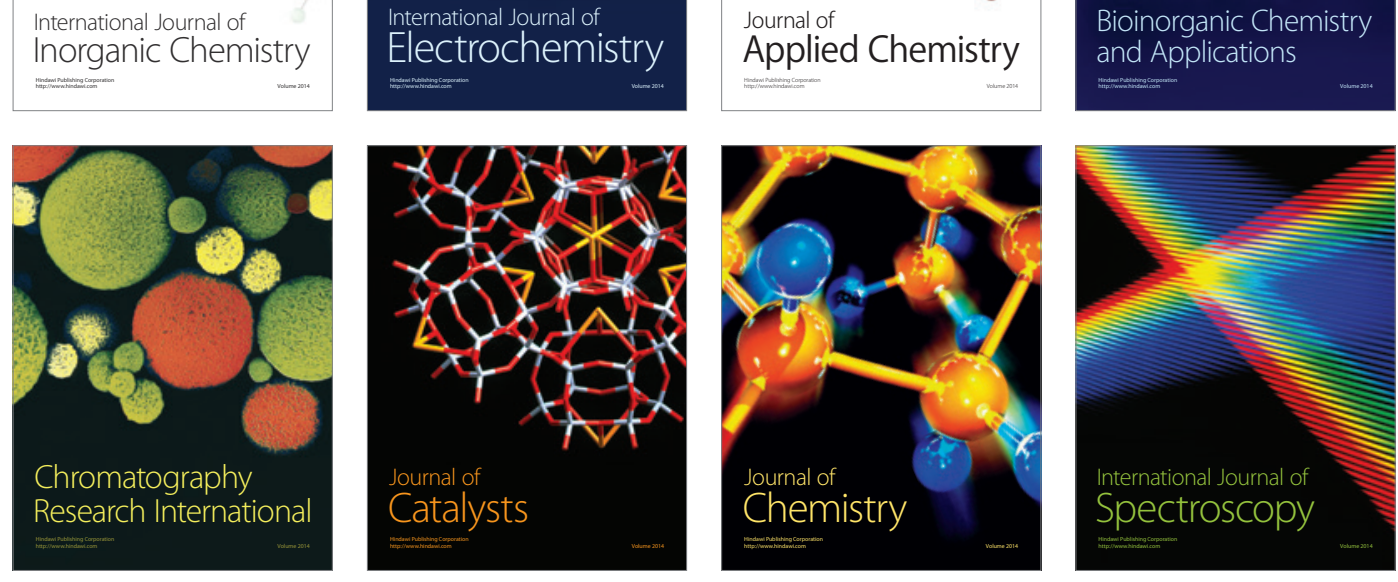